\title{
Breast Cancer Stem Cells and Their Role in Resistance to Endocrine Therapy
}

\author{
Ciara S. O'Brien • Gillian Farnie • Sacha J. Howell • \\ Robert B. Clarke
}

Published online: 22 January 2011

(C) Springer Science+Business Media, LLC 2011

\begin{abstract}
Developmentally, tumours can be viewed as aberrant versions of normal tissues. For example, tumours often retain differentiation markers of their tissue of origin. In addition, there is evidence that they contain cancer stemlike cells (CSCs) that drive tumourigenesis. In this review, we summarise current evidence that breast CSCs may partially explain endocrine resistance in breast cancer. In normal breast, the stem cells are known to possess a basal phenotype and to be mainly oestrogen receptor- $\alpha$-negative (ER-). If the hierarchy in breast cancer reflects this, the breast CSC may be endocrine resistant because it expresses very little ER and can only respond to treatment by virtue of paracrine signalling from neighbouring, differentiated ER+ tumour cells. Normal breast epithelial stem cells are regulated by the epidermal growth factor receptor and other growth factor receptor signals. The observed increase in growth factor receptor expression in endocrine-resistant breast cancers may reflect a bigger proportion of CSCs selected by endocrine therapies. There is evidence from a number of studies that breast CSCs are ER- and EGR+/ HER2+, which would support this view. It is reported that CSCs express mesenchymal genes, which are suppressed by ER expression, further indicating the mutual exclusion between ER+ cells and the CSCs. As we learn more about CSCs, differentiation and the expression and functional activity of the ER in these cells in diverse breast tumour sub-types, it is hoped that our understanding will lead to new modalities to overcome the problem of endocrine resistance in the clinic.
\end{abstract}

C. S. O’Brien · G. Farnie · S. J. Howell • R. B. Clarke $(\bowtie)$

Breast Biology Group, School of Cancer and Imaging Sciences, Paterson Institute for Cancer Research, University of Manchester, Wilmslow Road,

Manchester M20 4BX, UK

e-mail: robert.clarke@manchester.ac.uk
Keywords Cancer stem cells $\cdot$ Endocrine therapy Oestrogen receptor-alpha $\cdot$ Resistance

$\begin{array}{ll}\text { Abbreviations } \\ \text { CSC } & \text { Cancer stem-like cells } \\ \text { ER } & \text { Oestrogen receptor- } \alpha \\ \text { PR } & \text { Progesterone receptor } \\ \text { EGFR } & \text { Epidermal growth factor receptor } \\ \text { EMT } & \text { Epithelial mesenchymal transition } \\ \text { LN } & \text { Lymph node } \\ \text { ALDH1 } & \text { Aldehyde dehydrogenase 1 } \\ \text { HDAC } & \text { Histone deacetylase } \\ \text { DNMT } & \text { DNA methyl transferase }\end{array}$

\section{Introduction}

Developmentally, tumours can be viewed as aberrant versions of normal tissues. For example, tumours often retain differentiation markers of their tissue of origin. In normal development, adult tissues such as the mammary epithelium are derived from tissue-specific stem cells, which can be identified by specific cell surface markers and enriched using antibodies and flow cytometry before transplantation into new host animals to confirm that they can regenerate mammary epithelial tissue $[1,2]$. In human leukaemia, an infrequent population of stem-like cells with a surface-marker phenotype similar to normal hematopoietic stem cells have been shown to transfer the disease into immune-deficient mice supporting the idea that these cancers contain their own stem cell population [3]. The concept that epithelial and other solid tumours are aberrantly developed tissues containing a developmental hierarchy including cancer stem-like cells (CSCs) and more differentiated progenitor cells is supported 
by accumulating evidence. The frequency of this CSC population has been hotly disputed, ranging from very infrequent in leukaemia $(0.02 \%)$ to very frequent $(10-25 \%)$ in some transgenic models of lymphoma and human melanomas [3-5]. It appears CSC frequency in breast tumours may very well \depend on tumour grade, stage and molecular sub-type [6-8]. A significant role for the stromal microenvironment in determining CSC frequency also appears to be emerging [5]. However, there is no doubt that the evidence that CSCs are responsible for tumourigenesis, and cancer recurrence is becoming increasingly solid and needs to be considered for therapeutic decision-making in the clinic. Indeed analysis of drug compounds which may target cancer stem cells therapeutically have already begun $[9,10]$. In terms of clinical trials of novel therapies, it will be important to determine biomarkers for breast CSCs so that their successful targeting can be assessed. In this review, we will address the likely contribution of CSCs in oestrogen receptor- $\alpha$-positive $(E R+)$ breast tumours to endocrine resistance (reviewed in [11]) and explore the potential for targeting CSCs in order to re-sensitise them to treatment.

\section{Cancer Stem-Like Cells}

There is now a large body of evidence to show that leukaemia originates from an infrequent leukaemic stemlike cell. The first evidence for such CSCs described a small but variable proportion of human acute myeloid leukaemia (AML) cells which could be identified and purified with cell surface markers $\mathrm{CD} 34^{+} \mathrm{CD} 38^{-}$. These cells were found to be the only cells capable of transferring AML from human patients to NOD/SCID mice, providing evidence that not all AML cells have in vivo clonogenic capacity and only the small subset of CSCs was capable of regenerating the cancer [3]. Many groups have extrapolated the CSC hypothesis from the haematopoietic system to solid cancers and although the evidence for CSCs in solid cancers is in its infancy compared to the haematopoietic field, the body of supporting data is growing rapidly. Cells with CSC characteristics from human brain tumours (glioblastomas) were first isolated using clonogenic sphere culture technique to produce so-called neurospheres (NS) $[12,13]$. These NS cells are highly enriched for cell surface marker CD133 and nestin (a neural stem cell marker), have a marked capacity for proliferation, self-renewal and are capable of in vitro differentiation into phenotypes identical to the tumour in situ. CSC populations have also been found in prostate, colon and breast cancers [14-17].

In the breast, Al Hajj et al. [14] were the first to identify a subpopulation of human breast cancer cells which initiated tumours in immune-deficient NOD/SCID mice. They reported using a set of cell surface markers to sort cells with an increased tumourogenic capacity. Cells which were $\mathrm{CD}_{4} 4^{+}, \mathrm{CD} 24^{\text {low }}, \mathrm{ESA}^{+}$and lineage ${ }^{-}$(cells lacking markers CD2, CD3, CD10, CD16, CD18, CD31,CD64 and $\mathrm{CD} 140 \mathrm{~b}$ ), isolated from one primary breast cancer and eight metastases were able to form heterogeneous tumours eight out of nine times. The tumours contained not only the $\mathrm{CD} 44^{+}, \mathrm{CD} 24^{\mathrm{lo}}, \mathrm{ESA}^{+}$and lineage ${ }^{-}$tumour initiating cells but also the phenotypically diverse non-tumourigenic cells that comprise the bulk of tumours. As few as $200 \mathrm{CD}^{2} 4^{+} /$ $\mathrm{CD} 24^{\mathrm{lo}} / \mathrm{ESA}^{+} /$lineage ${ }^{-}$cells transplanted into NOD/SCID mice could form tumours with $100 \%$ efficiency, while no tumours formed using 200 cells from the $\mathrm{CD} 44^{-} / \mathrm{CD} 24^{+} /$ $\mathrm{ESA}^{-}$cell population. A subsequent study by Ponti et al. carried out on 16 breast lesions (13 primary invasive carcinomas, one recurrent carcinoma and two fibroadenomas) using the sphere culture technique resulted in the production of three long-term primary cultures which had self-renewing capacity and could differentiate into the different breast lineages [18]. Almost all sphere-derived cells were found to be $\mathrm{CD} 44^{+} / \mathrm{CD} 24^{\mathrm{lo}}$; however, cells with self renewal capacity only accounted for $10-20 \%$ of the total cell number, showing that only a sub-group within the $\mathrm{CD} 44^{+} / \mathrm{CD} 24^{\text {lo }}$ sorted cells had self-renewal capacity. This is consistent with only one in 200 cells being capable of initiating a tumour in the previous study. Tumour initiating capacity was measured in a long term sphere culture of the MCF7 breast cancer cell line, termed MCF-S. CD $44^{+} / \mathrm{CD} 24^{\text {lo }}$ cells from parental MCF7s were implanted into the mammary fat pad of SCID mice, and only gave rise to tumours when at least one million cells were implanted. However, CD $44^{+} / \mathrm{CD} 24^{\text {lo }}$ MCF-S cells gave rise to tumours with smaller numbers of cells [19-21] with at least a $60 \%$ success rate. Thus, both the mammosphere culture system and the cell surface marker selection enriched for tumour initiating cells in this study, importantly including breast cancers expressing ER. However, the enriched rather than pure CSC population that these methods produce and recent data suggesting that the regulation of $\mathrm{CD} 24$ is dynamic both in vitro and in vivo [22] has highlighted the need for additional markers to further discriminate the de facto CSC.

One such marker is aldehyde dehydrogenase (ALDH1), the cellular activity of which can be demonstrated using the fluorescent substrate Aldefluor and flow cytometric analysis [23]. ALDH1 activity has been shown to identify a stem/progenitor population in both human haematopoietic tissue and the normal mammary gland. Using primary human breast cancer samples cultivated as xenografts prior to disaggregation and sorting, Ginestier et al. demonstrated that only Aldefluor-positive cells could generate tumours in NOD/SCID mice. When combined with FACS analysis for $\mathrm{CD} 44 / 24 /$ lin the Aldefluor ${ }^{+} / \mathrm{CD} 44^{+} / \mathrm{CD} 24^{\mathrm{lo}} / \mathrm{lin}^{-}$population of cancer cells could reliably form tumours with as few as 20 cells in the innoculum, whereas 50,000 Aldefluor $^{-} /$ 
$\mathrm{CD} 44^{+} / \mathrm{CD} 24^{\mathrm{lo}} / \mathrm{lin}^{-}$cells failed to form tumours [24]. Importantly, however, recent data suggest that the Aldefluor assay may be less effective at discriminating CSC in breast cancer cell lines of luminal type [25].

There is also emerging evidence that some breast cancer cell lines will provide valuable and reliable models of tumour hierarchies containing CSCs with both cell sorting and xenografting being demonstrated from infrequent cell populations expressing markers such as CD44 and cytokeratin 5/6 and ALDH1 [25-27]. A common theme of many investigations into CSCs is that they have inherent resistance to chemo- and radiotherapy. This is proposed to be due to mechanisms such as more efficient DNA damage checkpoints and survival pathways compared to more differentiated tumour cell populations [28, 29]. We focus in the next section on how breast CSCs may have inherent resistance to endocrine therapies for a variety of reasons including their basal-like phenotype and the pathways that determine their stem cell-like behaviour.

Endocrine therapy remains a pivotal treatment for breast cancers which express ER. However, despite initial response to endocrine therapy, $25 \%$ of patients with early breast cancer and all patients with metastatic disease will eventually relapse [30]. We focus in the following sections on how breast CSCs may have inherent resistance to endocrine therapies for a variety of reasons including their basal-like phenotype and the pathways that determine their stem cell-like behaviour.

\section{Steroid Hormones and the Cellular Hierarchy of the Normal Breast}

The rudimentary mammary gland matures at puberty and functionally differentiates during pregnancy, lactation and menopause due to the influence of steroid hormones such as oestrogens and progesterones and epidermal growth factors [31-34]. This developmental plasticity at tissue level, suggests a stem cell population within the mammary gland which renews and differentiates to form a cellular hierarchy according to highly regulated functional cues. Human embryonic post mortem studies show absent expression of ER before 30 weeks gestation, although rudimentary mammary development commences from week 12 [35]. Moreover, ER knockout mice show no development of the breast beyond the rudimentary ductal structures of early gestation [36]. By contrast in the mature human mammary gland, $10-20 \%$ of luminal epithelial cells co-express ER and the progesterone receptor (PR) [37, 38]. PR expression is positively regulated by ER and thus indicates the presence of ER activity in a cell even where ER is undetectable. Interestingly $\mathrm{ER}+/ \mathrm{PR}+$ cells in mature mammary glands of both mice and humans do not actively divide but are in close proximity to mitotic cells [37, 38]. This would suggest a model where ER expression in the normal mammary gland is closely linked to a differentiated cell phenotype with limited replicative capacity (Fig. 1).

Interestingly, recent studies in mice and humans have suggested a more complicated role for the progesterone receptor in the post-pubertal mammary gland. Beleut et al. [39] have observed progesterone to be the main driver of proliferation in the adult murine mammary gland. Progesterone but not oestrogen stimulation in ovariectomised mice led to two waves of cellular proliferation, measured by BrdU incorporation labelling. The first small proliferative peak occurred in PR+ cells and was driven by cyclin D1. This was followed by a second and larger wave of proliferation in PR- cells RANKL (receptor activator of $\mathrm{NF}-\mathrm{KB}$ ligand) dependent manner. The authors postulated

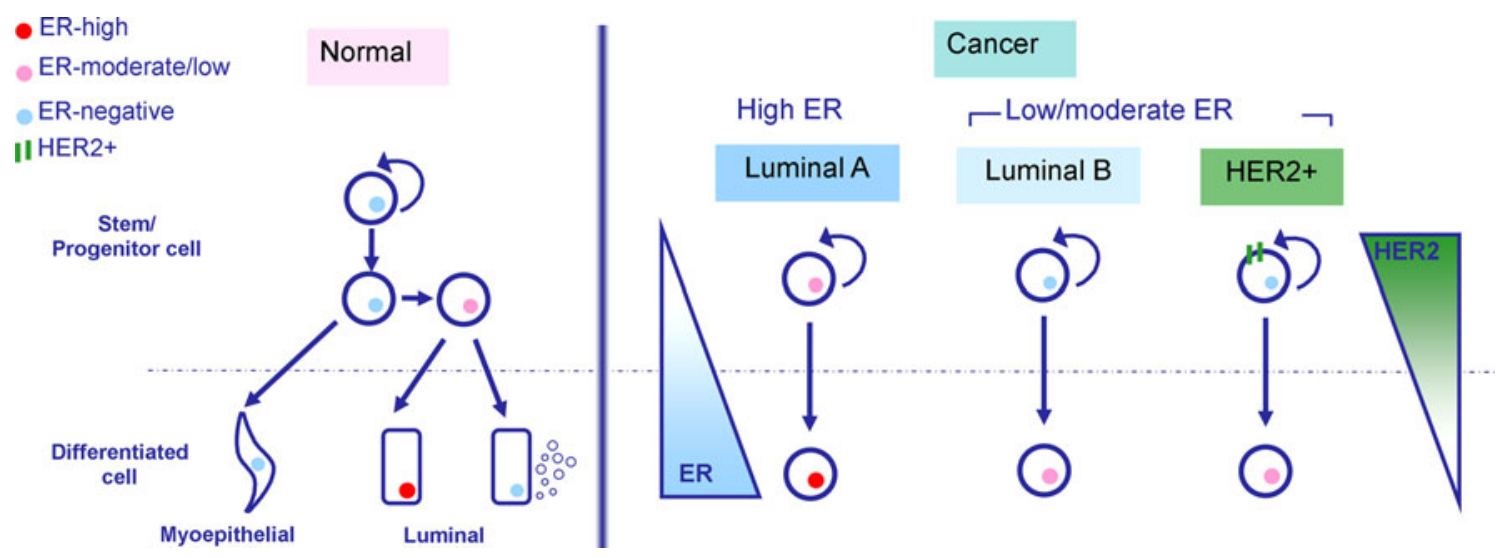

Fig. 1 Hypothetical cellular hierarchy of normal and malignant breast illustrating putative differential ER expression. In the normal breast, an ER- stem/progenitor cell either differentiates into an ERmyoepithelial cell lineage or via a ER moderate/low expressing progenitor will produce the luminal lineage which is either ER+ (nonmilk secreting) or ER- (milk secreting). Three different breast cancers are illustrated showing the Luminal A high ER+ tumours differentiating from ER low/moderate stem/progenitor cells. The Luminal B and HER2+ low to moderate ER tumours both differentiate from an ER- stem progenitor population. In the HER2+ tumours, the stem/ progenitor populations are highly HER $2+$ 
that $\mathrm{PR}+$ cells may play a progenitor role in the postpubertal mammary gland in contrast to the rudimentary mammary gland of early development [39].

The mouse mammary stem cell population characterised by expression of the markers CD $29^{\text {hi }}$ ( $\beta 1$ integrin)/CD $24^{+} /$ Lin $^{-}$[1] consists of less than $0.01 \%$ cells expressing ER $[40,41]$. Interestingly, epidermal growth factor receptor (EGFR) was found to be expressed in CD29 ${ }^{\text {hi }}$ ( $\beta 1$ integrin)/ $\mathrm{CD} 24^{+} / \mathrm{Lin}^{-}$although expression of PR and erbB2/HER2 receptor was absent [40]. A further murine study defined the cellular hierarchy further, separating the luminal compartment by expression of Sca1, CD133, CD24 and ER [42]. ER-rich $\mathrm{CD} 133^{+} / \mathrm{Sca}^{+} / \mathrm{CD} 24^{\text {hi }}$ cells were weakly proliferative whereas the milk-protein rich, ER low population of $\mathrm{CD} 133^{-} / \mathrm{Scal}^{-} / \mathrm{CD} 24^{\mathrm{hi}}$ cells showed high proliferative capacity.

In a study using normal human tissue derived from mammoplasties, Raouf et al. [43] defined bipotent progenitor cells, luminal committed progenitor cells and differentiated luminal cells by surface marker and subsequently assessed gene expression in each population. The cell sorting methods used enriched for primitive bipotent cells $\left(\mathrm{EpCAM}^{+} / \mathrm{CD} 4 \mathrm{f}^{\mathrm{hi}} / \mathrm{CALLA}(\mathrm{CD} 10)^{+} / \mathrm{Thy}^{+} / \mathrm{CD} 133^{-}\right)$at a purity of $45 \pm 3 \%$ (containing $57 \%$ of all bipotent cells) and luminal-restricted progenitors $\left(\mathrm{EpCAM}^{+} / \mathrm{CD} 4 \mathrm{f}^{+} / \mathrm{MUC1}^{+} /\right.$ $\mathrm{CD} 133^{+} / \mathrm{CD} 10^{-} / \mathrm{Thy}^{-}{ }^{-}$) at a purity of $32 \pm 3 \%$ (containing $96 \%$ of all luminal progenitor cells). Transcriptional profiling revealed $\mathrm{ER}^{\mathrm{lo}} / \mathrm{PR}^{\mathrm{hi}}$ expression in the bipotent cell population compared to $\mathrm{ER}^{\mathrm{hi}} / \mathrm{PR}^{\text {lo }}$ expression in the luminal committed progenitor population of the normal human breast, in an analogous manner to recent murine data [39]. These findings concur with the work of Shipitsin et al. [44] who determined $\mathrm{ER}^{\mathrm{lo}}$ expression of the stem cell population albeit defined by an alternative cell marker methodology $\left(\mathrm{CD} 44^{+} / \mathrm{PROCR}^{+} / \mathrm{CD} 24^{\mathrm{lo}}\right)$.

Finally, in exciting recent work, Asselin-Labat and colleagues [41] have investigated the role of steroid hormones in murine mammary stem cell function. Whilst demonstrating the adult mammary stem cell to be ER- and PR-, they observed that sensitivity to steroid hormones still remained as ovariectomy diminished the stem cell pool whereas pregnancy transiently increased stem cell number by 11 -fold in a RANKL-dependent manner. This links the increased breast cancer risk associated with pregnancy and cumulative oestrogen exposure with the mammary stem cell field.

\section{Breast Cancer Stem Cells and Endocrine Resistance}

In contrast to the normal mammary gland, actively dividing $\mathrm{ER}+$ cells are prominent in breast hyperplasia and breast cancers. The levels of ER and PR expression are predictive of treatment response rates to endocrine therapy and distinguish Luminal A tumours, which are highly ER+ and PR+, from luminal B and HER-2 tumours which have lower ER expression (Fig. 1), do not express PR and coexpress other growth factor receptors such as EGFR and erbB2 [45, 46]. Intrinsic and acquired resistance to endocrine therapy remains a significant cause of disease relapse and mortality in ER+ breast cancers [47, 48].

\section{EGFR Pathway}

Enhanced interaction between oestrogen receptor signalling and growth factor tyrosine kinase pathways such as EGFR, HER2/erbB2 and IGFR mediates resistance to endocrine therapy. For example, EGFR1 expression is inversely correlated with that of the ER and co-expression of both receptors confers relative resistance to endocrine therapy compared with tumours not expressing EGFR1 [46, 49]. A similar inverse expression relationship occurs between ER and erbB2/HER2. Tamoxifen-resistant MCF7 breast cancer cells show a 5-10-fold increase in mRNA and protein expression of erbB2/HER2 and the EGFR receptor compared to sensitive MCF7 cells [50]. Similarly, resistance to fulvestrant and aromatase inhibitors can also be mediated by upregulation of the erbB2 pathway [51]. Long-term stimulation of the EGFR and HER2/erbB2 pathways in endocrine resistant cancer cells down-regulates the ER. Ligand-independent activation of ER may be mediated by growth factor or intracellular kinase phosphorylation of the AF1 domain of ER, for example at serine 118 or 167 [52, 53] by MAPK, PI3K, akt and src-K [52, 54, 55], thus allowing expression of oestrogen-regulated gene products despite endocrine therapy. In two models of acquired endocrine resistance, long-term oestrogen-deprived (LTED) and tamoxifen-treated (TAM-R) cells, treatment with Lapatinib, a dual epidermal growth factor receptor inhibitor restored endocrine sensitivity [56]. In TAM-R cells, Lapatinib treatment led to reactivation of ER activity whereas in LTED cells which were exquisitely sensitive to oestrogen stimulation at baseline, lapatinib suppressed ER transcriptional activity. Intriguingly, the recent EGF30008 trial [57] demonstrated a significant improvement in progression free survival in HER2- patients with low ER expression who had relapsed within 6 months of tamoxifen discontinuation with dual treatment with letrozole (an aromatase inhibitor) combined with Lapatinib (13.6 months) compared to letrozole alone (6.7 months $p<0.005)$.

The acquisition of enhanced EGFR/erbB2 pathway signalling in ER+ breast cancer with tamoxifen resistance potentially results from selection of a more stem-like phenotype. Expression of EGFR has been demonstrated in stem cells of the normal mammary gland in mice and 
humans [40, 58]. This is in contrast to ER which is predominately expressed in more differentiated luminal cells [38, 42, 44]. In malignant CSCs, Farnie et al. [6] showed activation of the EGFR pathway ductal carcinoma in situ (DCIS) of the breast. Inhibition with gefitinib, an EGFR pathway inhibitor, significantly reduced mammosphere formation in vitro.

There is also emerging evidence for a role of the HER-2 pathway in the function of CSCs (Fig. 1). In one series of 491 breast cancer patients, expression of erbB2/HER2 and presence of ALDH1+ CSCs were positively correlated [24]. Recently, a report showed erbB2/HER2 over-expression enriched for normal and malignant stem cells in mammosphere and Aldefluor assays, increased in vitro clonogenicity and tumourigenicity in immunocompromised mice [59]. Separately, the CSC population of 4 HER2+ breast cancer cell lines have been demonstrated to express more HER-2 m-RNA and protein compared with the non-CSC cell population, regulated at the level of transcription. Furthermore, trastuzumab (Herceptin), reduced mammosphereforming capability and tumourigenicity on serial xenotransplantation [60]. In a clinical study in HER2 over-expressing large primary breast cancers, lapatinib (Tykerb; a dual EGFR/HER-2 tyrosine kinase inhibitor) reduced the $\mathrm{CD} 44^{+} / \mathrm{CD} 24^{\text {lo }} \mathrm{CSC}$ fraction and mammosphere forming efficiency of the residual tumour, although this did not reach formal statistical significance [61]. Notably treatment with chemotherapy alone increased the proportion of CSCs in the residual breast cancer [61, 62]. Thus, the reported upregulation of the EGFR/HER2 pathway in endocrine resistant breast cancer may in fact reflect an enrichment of a CSC phenotype.

\section{Notch Pathway}

An intriguing interaction is emerging between the Notch pathway, CSCs and endocrine treatment in breast cancer. The Notch pathway has been implicated in cell fate delineation in the normal human mammary gland [43, 63] and regulation of CSCs in DCIS [6] and invasive carcinoma of the breast [64, 65]. For example, Farnie et al. observed that inhibition of the Notch pathway by the gamma secretase inhibitor DAPT or a Notch 4 neutralising antibody significantly reduced mammosphere formation in primary human DCIS in vitro [6]. Similarly, recent work by Harrison et al. [66] demonstrated an 4- and 8-fold increase in Notch 1 and Notch 4 activity, respectively, in enriched CSC populations in breast cancer cell lines and invasive human breast cancers, compared to unsorted controls. Pharmacological and genetic inhibition of Notch 1 and Notch 4 in vitro and in vivo significantly reduced both CSC activity and overall tumour formation.
Breast cancer of luminal type has been shown to express low levels of Notch and ErbB2 but high levels of ER compared to basal breast cancers, which show the opposite pattern [67]. This inverse relationship between the expression of ER, ErbB2 and Notch activity in breast cancer may provide clues to the regulation of CSCs and endocrine resistance. While Magnifico et al. demonstrated that mammosphere formation in HER-2 overexpressing cell lines was significantly reduced by trastuzumab, the effect was ameliorated by antagonism of the Notch pathway [60]. The mechanism for this interaction between the Notch and EGFR pathway remains to be elucidated. However, this cross talk appears to be relevant therapeutically as Osipo et al. recently demonstrated a 2-6-fold increase in Notch 1 activity in MCF7, BT474 and SKBr3 cell lines after treatment with trastuzumab or lapatinib. Such treatment induced nuclear accumulation of Notch 1 intracellular domain and increased expression of Notch downstream targets including Hes 1, 5 and Hey 1. Inhibition of the Notch pathway led to re-sensitisation to trastuzumab and the combination of Notch antagonism and trastuzumab inhibited growth in both trastuzumab sensitive and resistant cell lines [68]. This is analogous to data reporting re-sensistation to Docetaxel and doxorubicin chemotherapy in breast cancer after RNAi mediated knockdown of Notch 1 [69].

Oestrogen signalling also down-regulates Notch signalling. Rizzo et al. demonstrated oestradiol induced reduction in the expression and activation of Notch 4 and Notch 1 in T47D and MCF7 cell lines. This reduction in Notch activity could be abrogated by tamoxifen and fulvestrant [67]. In a mouse xenotransplantation assay using the BT474 cell line, tumours were treated with tamoxifen alone or in combination with a gamma secretase inhibitor. Combination therapy was significantly superior to the use of tamoxifen alone and the authors conclude that tamoxifen antagonism of the oestrogen stimulus leads to the reactivation of the Notch signalling pathway promoting proliferation and survival. More recently, a potential mechanism of direct transcriptional crosstalk between Notch1 and ER target genes has been described via a nuclear IKK- dependent pathway [70]. However, further investigations will have to be carried out to determine whether this effect is on a cellular population level or specifically mediated by the CSC population.

\section{Cellular Hierarchy of Breast Cancer and ER Expression}

One mechanism of resistance to ER targeted endocrine therapy may be the presence of an ER-, treatmentresistant CSC population, with the capacity to differentiate and produce treatment sensitive ER+ luminal cancer 
cells. One prediction that follows from this proposed mechanism is that after endocrine treatment, there would remain a resistant population of $\mathrm{ER}^{-/ \mathrm{lo}}$ progenitor-like cells to seed relapse and metastases despite endocrine therapy.

In primary human breast cancer samples, Shipitsin et al. [44] used transcriptional profiling to characterise $\mathrm{CD}_{4} 4^{+} /$ $\mathrm{PROCR}^{+}$stem cells and $\mathrm{CD} 24^{+}$luminal type cells from the same donor. This group showed that $\mathrm{CD} 44^{+} / \mathrm{PROCR}^{+}$cells in breast cancers were enriched for stem cell markers and for gene expression related to cell motility and angiogenesis. Interestingly, malignant $\mathrm{CD} 44+$ cells were $\mathrm{ER}^{\mathrm{lo}}$ in a similar manner to $\mathrm{CD} 44^{+}$cells from normal mammoplasty specimens in this report and in a study by Fillmore and Kupperwasser $[26,44]$.

A recent paper has also demonstrated the presence of rare steroid receptor negative $\mathrm{CD} 44^{+}$cells present in the $\mathrm{ER}+$ breast cancer cell line T47D [27]. The size of this $\mathrm{CD} 44^{+} / \mathrm{CK} 5^{+} / \mathrm{ER}^{-} / \mathrm{PR}^{-}$did not proportionally increase with expansion of the rest of the tumour population and this infrequent ER- cell type was observed in both in vitro clonogenic and in vivo tumourigenic assays, whereas the bulk of the tumour consisted of proliferative $\mathrm{CD}_{4} 4^{-} /$ $\mathrm{CK} 5^{-} / \mathrm{ER}^{+} / \mathrm{PR}^{+}$cells. Notably an intermediate $\mathrm{CK}^{-} / \mathrm{ER}^{-} /$ $\mathrm{PR}^{+}$cell population was demonstrable in vitro colony assays when treated with progesterone. These defined populations within an ER+ cell line appears to mimic the cellular hierarchy of steroid receptor transcript expression in the normal breast as shown by Connie Eaves' group [43] and Cathrin Brisken's group [39]. Intriguingly, a role for the PR appears to emerge in a putative progenitor/intermediate cancer cell population.

Such findings are consistent with a model in which an ER- stem cell generates a cellular hierarchy at a metastatic site comparable to the hierarchy of the primary tumour (Fig. 1). Endocrine therapy in resistant patients, may enrich for the CSC population, in an analogous manner to the effects of chemotherapy or radiotherapy [61, 62, 71] leading to eventual relapse. Certainly, recent data suggest residual cancer cells after letrozole therapy are enriched in the CD44hi/CD24lo phenotype, mammosphere forming capacity and express markers of mesenchymal transition including vimentin and MMP2 [29]. However, this hypothesis, if the malignant cellular hierarchy is rigidly maintained, would require the CSCs to both rapidly self-renew and differentiate to generate $\mathrm{ER}+/ \mathrm{CD} 24+$ cells to maintain tumour growth despite the inhibitory effects of endocrine therapy on the $\mathrm{CD} 24+$ population. By contrast, it has recently been reported that $\mathrm{ER}+$ breast cancers with a gene signature similar to mammosphere derived gene sets were more frequently low grade $(p<0.001)$ of luminal A subtype $(p<0.001)$ with a superior overall survival rate over 10 years (HR 0.24 95\% CI $0.11-0.52$ )
[72]. From this study, the authors contend that survival from ER+ breast cancer is largely governed by cellular proliferation rather than cancer stem cell activity. However, as the mammospheres in this study were harvested on day 7 , it is possible that the cancer stem cell genetic signature may be obscured by that of the larger population of differentiated daughter cells within the spheroid colony at this time-point.

\section{Cancer Stem Cells, Mesenchymal Phenotype and Endocrine Resistance}

Work reported by Weinberg's group [73] has linked the mesenchymal phenotype to stem cells in normal tissue and to CSCs. Immortalised human mammary epithelial cells induced to undergo epithelial mesenchymal transition (EMT) exhibit stem cell markers and have increased capacity to form mammospheres enriched in stem cells. Similarly stem cells isolated from normal and cancerous human and mouse mammary glands demonstrate markers of mesenchymal phenotype normally apparent in EMT. These include up-regulation of the transcription factors Snail and Slug and the TGF $\beta$ signalling pathway which has been previously implicated in stem cell function [44].

Metastatic potential has long been associated with the loss of markers of the epithelial cell phenotype and the acquisition of basal/mesenchymal properties. Interestingly, recent analysis of a panel of breast cancer cell lines of luminal, intermediate and basal phenotypes demonstrated a significantly increased fraction of CSCs (defined by $\mathrm{CD} 44^{+} / \mathrm{CD} 24^{\mathrm{lo}} / \mathrm{ESA}^{+}$expression) in basal type breast cancers compared to hormone sensitive luminal cancers $(2.5 \%$ vs $0.5 \% p<0.0001)$ [26]. Furthermore, a positive correlation was shown between CSC number and cell line tumourigenicity in 'in vivo' models [26].

Endocrine resistant ER+ breast cancers are reported to gain a more basal phenotype, for example reduction in E-cadherin expression [74] and enhanced motility and invasion by upregulation of src kinase [75, 76], NF- $\mathrm{KB}$ [77] and CD44 $[78,79]$ and S. Hiscox unpublished observations. As ER negatively regulates the expression of the key transcription factors regulating EMT such as Snail and Slug [80, 81] a functionally redundant $\mathrm{ER}$ in endocrine resistant breast cancer might therefore promote a more mesenchymal stem-cell-like phenotype. Neoadjuvant letrozole therapy in one series of 36 patients [29] has demonstrated the comparative mesenchymal phenotype and claudin low signature [82] of residual cell types after systemic therapy. Residual cells showed enhanced expression of vimentin, fibronectin and Snail whereas expression of E-cadherin was diminished consistent with the acquisition of mesenchymal characteristics post-endocrine therapy. 


\section{Epigenetic Regulation of the Cellular Hierarchy}

Gene-expression profiling of breast cancer has demonstrated at least six distinct molecular subtypes: basal, erbB2, Luminal B, Luminal A, normal-like and claudin-low [45, 82, 83]. These subtypes probably represent a differentiation spectrum comparable to the developmental hierarchy of the breast; with poorly differentiated ER-negative basal type at one extreme to well differentiated Luminal A type at the other. As such, these subtypes may derive from a cell of origin at a different stage of the developmental hierarchy [84] and reflect the hormone and growth factor sensitivity of that distinct cell. Prolonged endocrine therapy may lead to the re-acquisition of a more primitive cancer cellular phenotype with intrinsic resistance to hormone manipulation.

A recent study elegantly demonstrates that targeted epigenetic modification of the genome has an important role to play in cell-fate determination in the cellular hierarchy of the human mammary gland and breast cancer [85]. Using methylation specific digital karyotyping and serial analysis of gene expression techniques, adult mammary stem cells $\left(\mathrm{CD} 44^{+}\right)$and breast cancer stem cells $\left(\mathrm{CSCs}-\mathrm{CD} 44^{+}\right)$were compared and contrasted to more lineage committed $\left(\mathrm{CD} 24^{+}\right)$cells. Normal adult mammary SCs and CSCs showed comparable genomic hypomethylation of transcription factors implicated in stem cell function such as HOXA10, FOXC1 and TCF3 compared to the more highly methylated progenitor and lineage committed cells. Forced expression of FOXC1 in differentiated mammary cells, where FOXC1 is normally methylated, led to the re-acquisition of a progenitor like phenotype. This suggests an important role for epigenetic modification in cell fate specification and function of normal and cancer stem cells, which in the future may be amenable to therapeutic targeting.

Acquired endocrine resistance may thus result from an alteration in cancer phenotype between the primary tumour and the metastases, to a more stem-like hormone insensitive cellular identity but the evidence for this remains circumstantial. In one series of 200 patients, $19.5 \%$ of metastases were found to be ER- in the presence of an ER+ primary breast cancer, and these findings have been replicated in another smaller study [86]. Fehm et al. have shown that in 88 patients with ER+ primary breast cancers, 76 had only ER- disseminated tumour cells (DTC) in the bone marrow [87]. These data raise the possibility that the ER- CSC is responsible for tumour metastasis and that cell surface phenotype of such cells facilitates communication with a stromal niche to enable intravasation and metastatic growth. It is worth noting that ER is lost completely in only $20 \%$ of metastases from ER+ primary cancers, suggesting that the ER-DTCs isolated by Fehm et al., undergo differentiation into tumours that can subsequently defined as ER+ [86]. Up to half of metastatic tumours which continue to express ER show no functional inhibition by endocrine agents. Interestingly, aberrant methylation of ER and PR promoters has been observed in up to $40 \%$ of hormone receptor negative breast cancers [88, 89] and epigenetic modifications have been shown in tamoxifen resistance [90]. Forced re-expression of ER by therapeutic demethylation may thus lead to the intriguing possibility of re-acquisition of endocrine sensitivity in these malignancies and we will discuss this possibility below.

\section{The Stem Cell Niche and Its Influence on Resistance to Endocrine Therapy}

CSCs are associated with increased invasive and metastatic/migratory phenotype [91-93]. Cells isolated as $\mathrm{CSC}$ by virtue of $\mathrm{ALDH}^{+}$and or $\mathrm{CD} 44^{+} / \mathrm{CD} 24^{\text {1o }}$ demonstrated increased metastasis from primary subcutaneous tumours in NOD/SCID/IL2 $\gamma$ receptor null mice. Such augmented invasive and metastatic phenotypes are also seen in endocrine-resistant breast cancer cell lines $[54,94,95]$. These cell lines exhibit over-expression of EGFR and the c-MET receptor through which they derive proliferative and migratory/invasive signals from stromal derived ligand secretion. Significantly, such resistant cells also over-express CD44, the adhesion of which to bonemarrow-derived endothelial cells is enhanced by stromalderived HGF in vitro $[79,96]$. Thus, adaptive endocrine resistance in cell lines is associated with a metastatic and stem cell-like phenotype.

Using human breast cancer cell lines in a murine model, it was demonstrated that CD44 was sparsely expressed in primary tumour cells but homogeneously over-expressed in cells transiting the lymphatics and populating lymph nodes (LN) [97]. The authors hypothesised that CD44 expression targeted tumour cells for metastasis to, and uptake in the $\mathrm{LN}$ although induction of CD44 expression by interaction of the epithelial cells with the LN stromal cells is also a possibility. The CD44 expressing cells were relatively insensitive to the effects of estradiol and estradiol withdrawal despite ER expression levels comparable to those seen in the primary tumours $[97,98]$. The same group have also recently shown that a small sub-population of the cells expressing CD44 express CK5 but not ER or PR and are resistant to both endocrine and chemotherapy [99]. Thus, the $\mathrm{LN}$ and stromal microenvironments may be responsible for maintenance of the CSC phenotype and suppression of oestrogen sensitivity in such cells.

Supporting the former hypothesis are recent data from Farmer et al. demonstrating a stroma-related gene signature in primary breast cancers [100]. This signature was associated with the presence of a reactive stroma and 
predicted for resistance to neo-adjuvant chemotherapy. Importantly the stroma-related signature demonstrated a pattern of expression similar to that of mammospheres suggesting that the stroma may support the CSC phenotype and promote resistance to therapy. As the signature was only tested in ER negative tumours, the relevance to luminal tumours and endocrine resistance is unknown but such analyses are eagerly awaited [100].

Another emerging target that is likely to impact on CSCs is antiangiogenic therapy since evidence is accumulating that both tissue stem cells and CSCs preferentially associate with blood vessels. For example, in oligodendrogliomas and glioblastomas, there is a direct correlation between nestin positive CSCs and microvessel density [101]. This study also reported that the CSCs preferentially associated with the $\mathrm{CD} 34^{+}$capillaries in vivo (in tumour sections) and endothelial vascular tubes in a basement membrane (Matrigel) culture assay in vitro compared with nonCSCs. In a prior report, this association had been shown to be secondary to CSC secretion of vascular endothelial growth factor, which directly stimulates endothelial cell growth [102]. Currently, there is little data to support or refute the existence of a vascular niche for the breast CSC and further investigation is required.

\section{Differentiation Agents and Endocrine Treatment}

There is evidence to show that histone deacetlylation and DNA methylation plays a key role in inactivation of ER gene expression. In ER- breast cancer cells, studies have demonstrated that the ER CpG promoter is occupied by abundant HDAC1 and HDAC2 [103, 104]. Similarly DNA methylation has also been reported to be up-regulated in ERbreast cancer cells [19]. Investigation of de novo ER gene methylation in vitro, showed DNA methyltransferase 1 (DNMT1) levels were significantly elevated in ER- breast cancer cell lines compared with their ER+ counterparts [89]. Furthermore, recent research into cell-type-specific DNA methylation patterns revealed that progenitors were hypomethylated compared to differentiated cells in the human normal breast and breast cancer [85]. The role of epigenetic modification in regulation of ER expression and the cell fate breast cancer may provide a therapeutic targeting strategy for ER- breast cancer patients.

Epigenetic therapies such as HDAC and DNMT inhibitors have shown considerable promise in the treatment of haematological malignancies [20] and trials are ongoing in solid cancers. Cell line studies have shown that functional ER gene expression can be induced by pharmacological administration of a DNMT inhibitor 5-aza-2'-deoxycytidine (AZA) and a HDAC inhibitor trichostatin A (TSA) [21, 105, 106]. Furthermore, combination AZA and TSA treatment acted synergistically to induce re-expression of ER in ERbreast cancer cells [107]. A recent pre-clinical xenograft model has demonstrated that $\mathrm{ER}^{-}$MDA-MB-435 cells treated with AZA and TSA re-expressed functional ER, which by itself caused a significant reduction in tumour growth. In addition, after ovarian ablation to mimic endocrine treatment, there was a further reduction in tumour growth [108]. Finally, using the clinical available HDAC inhibitor sodium valproate, Fortunati et al. [109] were also able to restore ER transcriptional activity to MDA MB231 cells and furthermore convey tamoxifen sensitivity to the previously tamoxifen insensitive HDAC treated cells in in vitro assays.

An inverse relationship between ER and EGFR expression has been well documented in breast cancer cell lines. Using the HDAC inhibitor vorinostat, two ER- cell lines, MDA-MB-231 and MDA-MB-468 cells, exhibit ER gene expression and reduced EGFR expression. Reduction in EGFR expression led to reduced EGFR signalling and PAK1 expression levels [110]. Interestingly, immuno-histochemical analysis of PAK1 shows significantly increased expression in breast cancers from hormone resistant patients [111-113].

HDAC inhibitors are being used in a number of ongoing clinical trials including a phase II trial evaluating vorinostat in ER positive patients with metastatic breast cancer who failed prior aromatase inhibitor therapy and up to three chemotherapy regimes [114]. A report of preliminary findings presented at ASCO 2008 showed that out of the 17 enrolled patients $21 \%$ had a partial response and $29 \%$ had stable disease after treatment with vorinostat $400 \mathrm{mg}$ daily for 3 of 4 weeks and tamoxifen $20 \mathrm{mg}$ daily, continuously. These findings suggest that the addition of an HDAC inhibitor to tamoxifen in patients who have failed prior aromatase inhibitors or adjuvant tamoxifen may restore hormone sensitivity. The in vitro studies would also suggest that HDAC inhibitors in combination with endocrine inhibitors may be highly applicable to ER- breast cancers as well.

\section{Conclusions}

We have summarised the current evidence that improving understanding of CSCs helps explain endocrine resistance in breast cancer. The biology of breast CSCs is becoming better characterised and the data suggest that they are resistant to endocrine therapy through diverse mechanisms. It is clear that knowledge of CSC biology and hierarchies in breast cancer can be better understood by examining what is known about the developmental hierarchy of the normal breast epithelium. In normal breast, the stem cells are known to possess a basal phenotype and to be mainly ER-. Thus, breast CSCs may be endocrine resistant because they 
express little ER and only respond to treatment by virtue of paracrine signalling from neighbouring, differentiated ER+ tumour cells. Normal breast epithelial stem cells are highly dependent on the EGFR and other growth factor receptors and the observed increased growth factor receptor expression in resistant breast cancers may reflect an increased proportion of stem-like cells selected by endocrine therapies. There is evidence from a number of studies that breast CSCs are ER- and CSCs also express mesenchymal proteins which are suppressed by ER expression, further indicating the mutual exclusion between ER + cells and the CSCs. It is likely that this is regulated at the epigenetic level, and differences in DNA methylation and chromatin organisation can be observed between breast CSCs and more differentiated populations. This may in turn be regulated extrinsically by the influence of stromal elements including the stem cell niche microenvironment associated with the vasculature, the lymph nodes and the bone marrow to which breast cancer cells often metastasise. It is known that the epigenetic programming can be remodelled by using drugs, particularly those that change the methylation and chromatin patterns of the DNA. Such drugs can effectively differentiate the cells, including potentially the $\mathrm{CSCs}$, leading to a reduction in growth factor receptors and an increase in ER+ cells, which may overcome resistance to endocrine agents in combination therapy. Such combinations are currently in clinical trials and their outcome is eagerly anticipated. As we understand more about CSCs, differentiation and the expression and functional activity of the ER in these cells in diverse tumour sub-types, it is hoped that it will lead to new modalities to overcome the problem of endocrine resistance in the clinic.

Acknowledgements CSO is a Cancer Research UK Clinical Training Fellow. GF and RBC are funded by Breast Cancer Campaign grants 2008MaySF01 and 2006MaySF01, respectively.

\section{References}

1. Shackleton M, Vaillant F, Simpson KJ, Stingl J, Smyth GK, Asselin-Labat ML, Wu L, Lindeman GJ, Visvader JE (2006) Generation of a functional mammary gland from a single stem cell. Nature 439:84-88

2. Stingl J, Eirew P, Ricketson I, Shackleton M, Vaillant F, Choi D, Li HI, Eaves CJ (2006) Purification and unique properties of mammary epithelial stem cells. Nature 439:993-997

3. Bonnet D, Dick JE (1997) Human acute myeloid leukemia is organized as a hierarchy that originates from a primitive hematopoietic cell. Nat Med 3:730-737

4. Kelly PN, Dakic A, Adams JM, Nutt SL, Strasser A (2007) Tumor growth need not be driven by rare cancer stem cells. Science 317:337

5. Quintana E, Shackleton M, Sabel MS, Fullen DR, Johnson TM, Morrison SJ (2008) Efficient tumour formation by single human melanoma cells. Nature 456:593-598
6. Farnie G, Clarke RB, Spence K, Pinnock N, Brennan K, Anderson NG, Bundred NJ (2007) Novel cell culture technique for primary ductal carcinoma in situ: role of Notch and epidermal growth factor receptor signalling pathways. J Natl Cancer Inst 99:616-627

7. Park SY, Lee HE, Li H, Shipitsin M, Gelman R, Polyak K (2010) Heterogeneity for stem cell-related markers according to tumor subtype and histologic stage in breast cancer. Clin Cancer Res $16: 876-887$

8. Pece S, Tosoni D, Confalonieri S, Mazzarol G, Vecchi M, Ronzoni S, Bernard L, Viale G, Pelicci PG, Di Fiore PP (2010) Biological and molecular heterogeneity of breast cancers correlates with their cancer stem cell content. Cell 140:62-73

9. Gupta PB, Onder TT, Jiang G, Tao K, Kuperwasser C, Weinberg RA, Lander ES (2009) Identification of selective inhibitors of cancer stem cells by high-throughput screening. Cell 138:645-659

10. Kakarala M, Brenner DE, Korkaya H, Cheng C, Tazi K, Ginestier C, Liu S, Dontu G, Wicha MS (2009) Targeting breast stem cells with the cancer preventive compounds curcumin and piperine. Breast Cancer Res Treat 122(3):777-785

11. Musgrove EA, Sutherland RL (2009) Biological determinants of endocrine resistance in breast cancer. Nat Rev Cancer 9:631-643

12. Singh SK, Clarke ID, Terasaki M, Bonn VE, Hawkins C, Squire J, Dirks PB (2003) Identification of a cancer stem cell in human brain tumors. Cancer Res 63:5821-5828

13. Singh SK, Hawkins C, Clarke ID, Squire JA, Bayani J, Hide T, Henkelman RM, Cusimano MD, Dirks PB (2004) Identification of human brain tumour initiating cells. Nature 432:396-401

14. Al-Hajj M, Wicha MS, Benito-Hernandez A, Morrison SJ, Clarke MF (2003) Prospective identification of tumorigenic breast cancer cells. Proc Natl Acad Sci USA 100:3983-3988

15. Collins AT, Berry PA, Hyde C, Stower MJ, Maitland NJ (2005) Prospective identification of tumorigenic prostate cancer stem cells. Cancer Res 65:10946-10951

16. O'Brien CA, Pollett A, Gallinger S, Dick JE (2007) A human colon cancer cell capable of initiating tumour growth in immunodeficient mice. Nature 445:106-110

17. Ricci-Vitiani L, Lombardi DG, Pilozzi E, Biffoni M, Todaro M, Peschle C, De Maria R (2007) Identification and expansion of human colon-cancer-initiating cells. Nature 445:111-115

18. Ponti D, Costa A, Zaffaroni N, Pratesi G, Petrangolini G, Coradini D, Pilotti S, Pierotti MA, Daidone MG (2005) Isolation and in vitro propagation of tumorigenic breast cancer cells with stem/progenitor cell properties. Cancer Res 65:5506-5511

19. Cameron EE, Bachman KE, Myohanen S, Herman JG, Baylin SB (1999) Synergy of demethylation and histone deacetylase inhibition in the re-expression of genes silenced in cancer. Nat Genet 21:103-107

20. Lyko F, Brown R (2005) DNA methyltransferase inhibitors and the development of epigenetic cancer therapies. J Natl Cancer Inst 97:1498-1506

21. Bovenzi V, Momparler RL (2001) Antineoplastic action of 5 -aza-2'-deoxycytidine and histone deacetylase inhibitor and their effect on the expression of retinoic acid receptor beta and estrogen receptor alpha genes in breast carcinoma cells. Cancer Chemother Pharmacol 48:71-76

22. Meyer MJ, Fleming JM, Ali MA, Pesesky MW, Ginsburg E, Vonderhaar BK (2009) Dynamic regulation of CD24 and the invasive, CD44posCD24neg phenotype in breast cancer cell lines. Breast Cancer Res 11:R82

23. Storms RW, Trujillo AP, Springer JB, Shah L, Colvin OM, Ludeman SM, Smith C (1999) Isolation of primitive human hematopoietic progenitors on the basis of aldehyde dehydrogenase activity. Proc Natl Acad Sci USA 96:9118-9123

24. Ginestier C, Hur MH, Charafe-Jauffret E, Monville F, Dutcher J, Brown M, Jacquemier J, Viens P, Kleer CG, Liu S, Schott A, 
Hayes D, Birnbaum D, Wicha MS, Dontu G (2007) ALDH1 is a marker of normal and malignant human mammary stem cells and a predictor of poor clinical outcome. Cell Stem Cell $1: 555-567$

25. Charafe-Jauffret E, Ginestier C, Iovino F, Wicinski J, Cervera N, Finetti P, Hur MH, Diebel ME, Monville F, Dutcher J, Brown M, Viens P, Xerri L, Bertucci F, Stassi G, Dontu G, Birnbaum D, Wicha MS (2009) Breast cancer cell lines contain functional cancer stem cells with metastatic capacity and a distinct molecular signature. Cancer Res 69:1302-1313

26. Fillmore CM, Kuperwasser C (2008) Human breast cancer cell lines contain stem-like cells that self-renew, give rise to phenotypically diverse progeny and survive chemotherapy. Breast Cancer Res 10:R25

27. Horwitz KB, Dye WW, Harrell JC, Kabos P, Sartorius CA (2008) Rare steroid receptor-negative basal-like tumorigenic cells in luminal subtype human breast cancer xenografts. Proc Natl Acad Sci USA 105:5774-5779

28. Zhang M, Atkinson RL, Rosen JM (2010) Selective targeting of radiation-resistant tumor-initiating cells. Proc Natl Acad Sci USA 107:3522-3527

29. Creighton CJ, Li X, Landis M, Dixon JM, Neumeister VM, Sjolund A, Rimm DL, Wong H, Rodriguez A, Herschkowitz JI, Fan C, Zhang X, He X, Pavlick A, Gutierrez MC, Renshaw L, Larionov AA, Faratian D, Hilsenbeck SG, Perou CM, Lewis MT, Rosen JM, Chang JC (2009) Residual breast cancers after conventional therapy display mesenchymal as well as tumorinitiating features. Proc Natl Acad Sci USA 106:13820-13825

30. Howell A, Wardley AM (2005) Overview of the impact of conventional systemic therapies on breast cancer. Endocr Relat Cancer 12(Suppl 1):S9-S16

31. Mallepell S, Krust A, Chambon P, Brisken C (2006) Paracrine signalling through the epithelial estrogen receptor alpha is required for proliferation and morphogenesis in the mammary gland. Proc Natl Acad Sci USA 103:2196-2201

32. Brisken C, Kaur S, Chavarria TE, Binart N, Sutherland RL, Weinberg RA, Kelly PA, Ormandy CJ (1999) Prolactin controls mammary gland development via direct and indirect mechanisms. Dev Biol 210:96-106

33. Coleman S, Silberstein GB, Daniel CW (1988) Ductal morphogenesis in the mouse mammary gland: evidence supporting a role for epidermal growth factor. Dev Biol 127:304-315

34. Brisken C, Park S, Vass T, Lydon JP, O’Malley BW, Weinberg RA (1998) A paracrine role for the epithelial progesterone receptor in mammary gland development. Proc Natl Acad Sci USA 95:5076-5081

35. Keeling JW, Ozer E, King G, Walker F (2000) Oestrogen receptor alpha in female fetal, infant, and child mammary tissue. J Pathol 191:449-451

36. Korach KS, Couse JF, Curtis SW, Washburn TF, Lindzey J, Kimbro KS, Eddy EM, Migliaccio S, Snedeker SM, Lubahn DB, Schomberg DW, Smith EP (1996) Estrogen receptor gene disruption: molecular characterization and experimental and clinical phenotypes. Recent Prog Horm Res 51:159-186, discussion 186-158

37. Russo J, Ao X, Grill C, Russo IH (1999) Pattern of distribution of cells positive for estrogen receptor alpha and progesterone receptor in relation to proliferating cells in the mammary gland. Breast Cancer Res Treat 53:217-227

38. Clarke RB, Howell A, Potten CS, Anderson E (1997) Dissociation between steroid receptor expression and cell proliferation in the human breast. Cancer Res 57:4987-4991

39. Beleut M, Rajaram RD, Caikovski M, Ayyanan A, Germano D, Choi Y, Schneider P, Brisken C (2010) Two distinct mechanisms underlie progesterone-induced proliferation in the mammary gland. Proc Natl Acad Sci USA 107:2989-2994
40. Asselin-Labat ML, Shackleton M, Stingl J, Vaillant F, Forrest NC, Eaves CJ, Visvader JE, Lindeman GJ (2006) Steroid hormone receptor status of mouse mammary stem cells. J Natl Cancer Inst 98:1011-1014

41. Asselin-Labat ML, Vaillant F, Sheridan JM, Pal B, Wu D, Simpson ER, Yasuda H, Smyth GK, Martin TJ, Lindeman GJ, Visvader JE (2010) Control of mammary stem cell function by steroid hormone signalling. Nature 465(7299):798-802

42. Sleeman KE, Kendrick H, Robertson D, Isacke CM, Ashworth A, Smalley MJ (2007) Dissociation of estrogen receptor expression and in vivo stem cell activity in the mammary gland. J Cell Biol 176:19-26

43. Raouf A, Zhao Y, To K, Stingl J, Delaney A, Barbara M, Iscove N, Jones S, McKinney S, Emerman J, Aparicio S, Marra M, Eaves C (2008) Transcriptome analysis of the normal human mammary cell commitment and differentiation process. Cell Stem Cell 3:109-118

44. Shipitsin M, Campbell LL, Argani P, Weremowicz S, Bloushtain-Qimron N, Yao J, Nikolskaya T, Serebryiskaya T, Beroukhim R, Hu M, Halushka MK, Sukumar S, Parker LM, Anderson KS, Harris LN, Garber JE, Richardson AL, Schnitt SJ, Nikolsky Y, Gelman RS, Polyak K (2007) Molecular definition of breast tumor heterogeneity. Cancer Cell 11:259-273

45. Sorlie T, Tibshirani R, Parker J, Hastie T, Marron JS, Nobel A, Deng S, Johnsen H, Pesich R, Geisler S, Demeter J, Perou CM, Lonning PE, Brown PO, Borresen-Dale AL, Botstein D (2003) Repeated observation of breast tumor subtypes in independent gene expression data sets. Proc Natl Acad Sci USA 100:8418-8423

46. Dowsett M, Houghton J, Iden C, Salter J, Farndon J, A'Hern R, Sainsbury R, Baum M (2006) Benefit from adjuvant tamoxifen therapy in primary breast cancer patients according oestrogen receptor, progesterone receptor, EGF receptor and HER2 status. Ann Oncol 17:818-826

47. Howell A, Cuzick J, Baum M, Buzdar A, Dowsett M, Forbes JF, Hoctin-Boes G, Houghton J, Locker GY, Tobias JS (2005) Results of the ATAC (Arimidex, Tamoxifen, Alone or in Combination) trial after completion of 5 years' adjuvant treatment for breast cancer. Lancet 365:60-62

48. Gelber RD, Cole BF, Goldhirsch A, Rose C, Fisher B, Osborne CK, Boccardo F, Gray R, Gordon NH, Bengtsson NO, Sevelda P (1996) Adjuvant chemotherapy plus tamoxifen compared with tamoxifen alone for postmenopausal breast cancer: meta-analysis of qualityadjusted survival. Lancet 347:1066-1071

49. Giltnane JM, Ryden L, Cregger M, Bendahl PO, Jirstrom K, Rimm DL (2007) Quantitative measurement of epidermal growth factor receptor is a negative predictive factor for tamoxifen response in hormone receptor positive premenopausal breast cancer. J Clin Oncol 25:3007-3014

50. Knowlden JM, Hutcheson IR, Jones HE, Madden T, Gee JM, Harper ME, Barrow D, Wakeling AE, Nicholson RI (2003) Elevated levels of epidermal growth factor receptor/c-erbB2 heterodimers mediate an autocrine growth regulatory pathway in tamoxifen-resistant MCF-7 cells. Endocrinology 144:1032-1044

51. Massarweh S, Osborne CK, Jiang S, Wakeling AE, Rimawi M, Mohsin SK, Hilsenbeck S, Schiff R (2006) Mechanisms of tumor regression and resistance to estrogen deprivation and fulvestrant in a model of estrogen receptor-positive, HER-2/neu-positive breast cancer. Cancer Res 66:8266-8273

52. Pancholi S, Lykkesfeldt A, Hilmi C, Banerjee S, Leary A, Drury S, Johnston S, Dowsett M, Martin LA (2008) ERBB2 influences the subcellular localization of the estrogen receptor in tamoxifenresistant MCF-7 cells leading to the activation of AKT and p90RSK. Endocr Relat Cancer 15:985

53. Sarwar N, Kim JS, Jiang J, Peston D, Sinnett HD, Madden P, Gee JM, Nicholson RI, Lykkesfeldt AE, Shousha S, Coombes RC, Ali S (2006) Phosphorylation of ERalpha at serine 118 in primary 
breast cancer and in tamoxifen-resistant tumours is indicative of a complex role for ERalpha phosphorylation in breast cancer progression. Endocr Relat Cancer 13:851-861

54. Hiscox S, Morgan L, Green TP, Barrow D, Gee J, Nicholson RI (2006) Elevated Src activity promotes cellular invasion and motility in tamoxifen resistant breast cancer cells. Breast Cancer Res Treat 97:263-274

55. Campbell RA, Bhat-Nakshatri P, Patel NM, Constantinidou D, Ali S, Nakshatri H (2001) Phosphatidylinositol 3-kinase/AKT-mediated activation of estrogen receptor alpha: a new model for anti-estrogen resistance. J Biol Chem 276:9817-9824

56. Leary AF, Drury S, Detre S, Pancholi S, Lykkesfeldt AE, Martin LA, Dowsett M, Johnston SR (2010) Lapatinib restores hormone sensitivity with differential effects on estrogen receptor signalling in cell models of human epidermal growth factor receptor 2-negative breast cancer with acquired endocrine resistance. Clin Cancer Res 16:1486-1497

57. Johnston S, Pippen J Jr, Pivot X, Lichinitser M, Sadeghi S, Dieras V, Gomez HL, Romieu G, Manikhas A, Kennedy MJ, Press MF, Maltzman J, Florance A, O'Rourke L, Oliva C, Stein S, Pegram M (2009) Lapatinib combined with letrozole versus letrozole and placebo as first-line therapy for postmenopausal hormone receptor-positive metastatic breast cancer. J Clin Oncol 27:5538-5546

58. Hebbard L, Steffen A, Zawadzki V, Fieber C, Howells N, Moll J, Ponta H, Hofmann M, Sleeman J (2000) CD44 expression and regulation during mammary gland development and function. J Cell Sci 113(Pt 14):2619-2630

59. Korkaya H, Paulson A, Iovino F, Wicha MS (2008) HER2 regulates the mammary stem/progenitor cell population driving tumorigenesis and invasion. Oncogene 27:6120-6130

60. Magnifico AAL, Campaner S, Delia D, Castiglioni F, Gasparini P, Sozzi GFE, Menard S, Tagliabue E (2009) Tumor-initiating cells of HER2-positive carcinoma cell lines express the highest oncoprotein levels and are sensitive to trastuzumab. Clin Cancer Res 15:2010-2021

61. Li X, Lewis MT, Huang J, Gutierrez C, Osborne CK, Wu MF, Hilsenbeck SG, Pavlick A, Zhang X, Chamness GC, Wong H, Rosen J, Chang JC (2008) Intrinsic resistance of tumorigenic breast cancer cells to chemotherapy. J Natl Cancer Inst 100:672-679

62. Yu F, Yao H, Zhu P, Zhang X, Pan Q, Gong C, Huang Y, Hu X, Su F, Lieberman J, Song E (2007) let-7 regulates self renewal and tumorigenicity of breast cancer cells. Cell 131:1109-1123

63. Yalcin-Ozuysal O, Fiche M, Guitierrez M, Wagner KU, Raffoul W, Brisken C (2010) Antagonistic roles of Notch and p63 in controlling mammary epithelial cell fates. Cell Death Differ 17 (10): $1600-1612$

64. Dontu G, Jackson KW, McNicholas E, Kawamura MJ, Abdallah WM, Wicha MS (2004) Role of Notch signalling in cell-fate determination of human mammary stem/progenitor cells. Breast Cancer Res 6:R605-R615

65. Stylianou S, Clarke RB, Brennan K (2006) Aberrant activation of notch signalling in human breast cancer. Cancer Res $66: 1517-1525$

66. Harrison H, Farnie G, Howell SJ, Rock RE, Stylianou S, Brennan KR, Bundred NJ, Clarke RB (2010) Regulation of breast cancer stem cell activity by signalling through the Notch4 receptor. Cancer Res 70:709-718

67. Rizzo P, Miao H, D’Souza G, Osipo C, Song LL, Yun J, Zhao H, Mascarenhas J, Wyatt D, Antico G, Hao L, Yao K, Rajan P, Hicks C, Siziopikou K, Selvaggi S, Bashir A, Bhandari D, Marchese A, Lendahl U, Qin JZ, Tonetti DA, Albain K, Nickoloff BJ, Miele L (2008) Cross-talk between notch and the estrogen receptor in breast cancer suggests novel therapeutic approaches. Cancer Res 68:5226-5235
68. Osipo C, Patel P, Rizzo P, Clementz AG, Hao L, Golde TE, Miele L (2008) ErbB-2 inhibition activates Notch-1 and sensitizes breast cancer cells to a gamma-secretase inhibitor. Oncogene 27:5019-5032

69. Zang S, Chen F, Dai J, Guo D, Tse W, Qu X, Ma D, Ji C (2010) RNAi-mediated knockdown of Notch-1 leads to cell growth inhibition and enhanced chemosensitivity in human breast cancer. Oncol Rep 23:893-899

70. Hao L, Rizzo P, Osipo C, Pannuti A, Wyatt D, Cheung LW, Sonenshein G, Osborne BA, Miele L (2010) Notch-1 activates estrogen receptor-alpha-dependent transcription via IKKalpha in breast cancer cells. Oncogene 29:201-213

71. Phillips TM, McBride WH, Pajonk F (2006) The response of CD24(-/low)/CD44+ breast cancer-initiating cells to radiation. J Natl Cancer Inst 98:1777-1785

72. Kok M, Koornstra RH, Margarido TC, Fles R, Armstrong NJ, Linn SC, Van't Veer LJ, Weigelt B (2009) Mammospherederived gene set predicts outcome in patients with ER-positive breast cancer. J Pathol 218:316-326

73. Mani SA, Guo W, Liao MJ, Eaton EN, Ayyanan A, Zhou AY, Brooks M, Reinhard F, Zhang CC, Shipitsin M, Campbell LL, Polyak K, Brisken C, Yang J, Weinberg RA (2008) The epithelial-mesenchymal transition generates cells with properties of stem cells. Cell 133:704-715

74. Hiscox S, Jiang WG, Obermeier K, Taylor K, Morgan L, Burmi R, Barrow D, Nicholson RI (2006) Tamoxifen resistance in MCF7 cells promotes EMT-like behaviour and involves modulation of beta-catenin phosphorylation. Int $\mathrm{J}$ Cancer 118:290-301

75. Hiscox S, Jordan NJ, Morgan L, Green TP, Nicholson RI (2007) Src kinase promotes adhesion-independent activation of FAK and enhances cellular migration in tamoxifen-resistant breast cancer cells. Clin Exp Metastasis 24:157-167

76. Hiscox S, Jordan NJ, Smith C, James M, Morgan L, Taylor KM, Green TP, Nicholson RI (2008) Dual targeting of Src and ER prevents acquired antihormone resistance in breast cancer cells. Breast Cancer Res Treat 115(1):57-67

77. Zhou Y, Yau C, Gray JW, Chew K, Dairkee SH, Moore DH, Eppenberger U, Eppenberger-Castori S, Benz CC (2007) Enhanced NF kappa B and AP-1 transcriptional activity associated with antiestrogen resistant breast cancer. BMC Cancer 7:59

78. Borley AC, Hiscox S, Gee J, Smith C, Shaw V, Barrett-Lee P, Nicholson RI (2008) Anti-oestrogens but not oestrogen deprivation promote cellular invasion in intercellular adhesion-deficient breast cancer cells. Breast Cancer Res 10:R103

79. Hiscox S, Jiang WG (1997) Regulation of endothelial CD44 expression and endothelium-tumour cell interactions by hepatocyte growth factor/scatter factor. Biochem Biophys Res Commun 233:1-5

80. Dhasarathy A, Kajita M, Wade PA (2007) The transcription factor snail mediates epithelial to mesenchymal transitions by repression of estrogen receptor-alpha. Mol Endocrinol 21:2907-2918

81. Ye Y, Xiao Y, Wang W, Yearsley K, Gao JX, Barsky SH (2008) ERalpha suppresses slug expression directly by transcriptional repression. Biochem J 416:179-187

82. Herschkowitz JI, Simin K, Weigman VJ, Mikaelian I, Usary J, Hu Z, Rasmussen KE, Jones LP, Assefnia S, Chandrasekharan S, Backlund MG, Yin Y, Khramtsov AI, Bastein R, Quackenbush J, Glazer RI, Brown PH, Green JE, Kopelovich L, Furth PA, Palazzo JP, Olopade OI, Bernard PS, Churchill GA, Van Dyke T, Perou CM (2007) Identification of conserved gene expression features between murine mammary carcinoma models and human breast tumors. Genome Biol 8:R76 
83. Perou CM, Sorlie T, Eisen MB, van de Rijn M, Jeffrey SS, Rees CA, Pollack JR, Ross DT, Johnsen H, Akslen LA, Fluge O, Pergamenschikov A, Williams C, Zhu SX, Lonning PE, Borresen-Dale AL, Brown PO, Botstein D (2000) Molecular portraits of human breast tumours. Nature 406:747-752

84. Sims AH, Howell A, Howell SJ, Clarke RB (2007) Origins of breast cancer subtypes and therapeutic implications. Nat Clin Pract Oncol 4:516-525

85. Bloushtain-Qimron N, Yao J, Snyder EL, Shipitsin M, Campbell LL, Mani SA, Hu M, Chen H, Ustyansky V, Antosiewicz JE, Argani P, Halushka MK, Thomson JA, Pharoah P, Porgador A, Sukumar S, Parsons R, Richardson AL, Stampfer MR, Gelman RS, Nikolskaya T, Nikolsky Y, Polyak K (2008) Cell typespecific DNA methylation patterns in the human breast. Proc Natl Acad Sci USA 105:14076-14081

86. Lower EE, Glass EL, Bradley DA, Blau R, Heffelfinger S (2005) Impact of metastatic estrogen receptor and progesterone receptor status on survival. Breast Cancer Res Treat 90:65-70

87. Fehm T, Krawczyk N, Solomayer EF, Becker-Pergola G, DurrStorzer S, Neubauer H, Seeger H, Staebler A, Wallwiener D, Becker S (2008) ERalpha-status of disseminated tumour cells in bone marrow of primary breast cancer patients. Breast Cancer Res 10:R76

88. Lapidus RG, Ferguson AT, Ottaviano YL, Parl FF, Smith HS, Weitzman SA, Baylin SB, Issa JP, Davidson NE (1996) Methylation of estrogen and progesterone receptor gene $5^{\prime} \mathrm{CpG}$ islands correlates with lack of estrogen and progesterone receptor gene expression in breast tumors. Clin Cancer Res 2:805-810

89. Ottaviano YL, Issa JP, Parl FF, Smith HS, Baylin SB, Davidson NE (1994) Methylation of the estrogen receptor gene CpG island marks loss of estrogen receptor expression in human breast cancer cells. Cancer Res 54:2552-2555

90. Badia E, Oliva J, Balaguer P, Cavailles V (2007) Tamoxifen resistance and epigenetic modifications in breast cancer cell lines. Curr Med Chem 14:3035-3045

91. Croker AK, Goodale D, Chu J, Postenka C, Hedley BD, Hess DA, Allan AL (2008) High aldehyde dehydrogenase and expression of cancer stem cell markers selects for breast cancer cells with enhanced malignant and metastatic ability. J Cell Mol Med 13(8):2236-2252

92. Sheridan C, Kishimoto H, Fuchs RK, Mehrotra S, BhatNakshatri P, Turner CH, Goulet R Jr, Badve S, Nakshatri H (2006) CD44+/CD24- breast cancer cells exhibit enhanced invasive properties: an early step necessary for metastasis. Breast Cancer Res 8:R59

93. Ouhtit A, Abd Elmageed ZY, Abdraboh ME, Lioe TF, Raj MH (2007) In vivo evidence for the role of CD44s in promoting breast cancer metastasis to the liver. Am J Pathol 171:2033-2039

94. Hiscox S, Jordan NJ, Jiang W, Harper M, McClelland R, Smith C, Nicholson RI (2006) Chronic exposure to fulvestrant promotes overexpression of the c-Met receptor in breast cancer cells: implications for tumour-stroma interactions. Endocr Relat Cancer 13:1085-1099

95. Hiscox S, Morgan L, Barrow D, Dutkowskil C, Wakeling A, Nicholson RI (2004) Tamoxifen resistance in breast cancer cells is accompanied by an enhanced motile and invasive phenotype: inhibition by gefitinib ('Iressa', ZD1839). Clin Exp Metastasis 21:201-212

96. Mine S, Fujisaki T, Kawahara C, Tabata T, Iida T, Yasuda M, Yoneda T, Tanaka Y (2003) Hepatocyte growth factor enhances adhesion of breast cancer cells to endothelial cells in vitro through up-regulation of CD44. Exp Cell Res 288:189-197

97. Harrell JC, Dye WW, Allred DC, Jedlicka P, Spoelstra NS, Sartorius CA, Horwitz KB (2006) Estrogen receptor positive breast cancer metastasis: altered hormonal sensitivity and tumor aggressiveness in lymphatic vessels and lymph nodes. Cancer Res 66:9308-9315

98. Harrell JC, Dye WW, Harvell DM, Pinto M, Jedlicka P, Sartorius CA, Horwitz KB (2007) Estrogen insensitivity in a model of estrogen receptor positive breast cancer lymph node metastasis. Cancer Res 67:10582-10591

99. Kabos PDW, Elias A, Horwitz KB, Sartorius CA (2008) The chemoresistant population of luminal subtype human breast cancer cells expresses a basal phenotype. San Antonio Breast Cancer Symposium Proceedings, Abstract presentation

100. Farmer P, Bonnefoi H, Anderle P, Cameron D, Wirapati P, Becette V, Andre S, Piccart M, Campone M, Brain E, Macgrogan G, Petit T, Jassem J, Bibeau F, Blot E, Bogaerts J, Aguet M, Bergh J, Iggo R, Delorenzi M (2009) A stroma-related gene signature predicts resistance to neoadjuvant chemotherapy in breast cancer. Nat Med 15:68-74

101. Calabrese C, Poppleton H, Kocak M, Hogg TL, Fuller C, Hamner B, Oh EY, Gaber MW, Finklestein D, Allen M, Frank A, Bayazitov IT, Zakharenko SS, Gajjar A, Davidoff A, Gilbertson RJ (2007) A perivascular niche for brain tumor stem cells. Cancer Cell 11:69-82

102. Bao S, Wu Q, Sathornsumetee S, Hao Y, Li Z, Hjelmeland AB, Shi Q, McLendon RE, Bigner DD, Rich JN (2006) Stem cell-like glioma cells promote tumor angiogenesis through vascular endothelial growth factor. Cancer Res 66:7843-7848

103. Sharma D, Blum J, Yang X, Beaulieu N, Macleod AR, Davidson NE (2005) Release of methyl CpG binding proteins and histone deacetylase 1 from the Estrogen receptor alpha (ER) promoter upon reactivation in ER-negative human breast cancer cells. Mol Endocrinol 19:1740-1751

104. Zhou Q, Atadja P, Davidson NE (2007) Histone deacetylase inhibitor LBH589 reactivates silenced estrogen receptor alpha (ER) gene expression without loss of DNA hypermethylation. Cancer Biol Ther 6:64-69

105. Ferguson AT, Lapidus RG, Baylin SB, Davidson NE (1995) Demethylation of the estrogen receptor gene in estrogen receptor-negative breast cancer cells can reactivate estrogen receptor gene expression. Cancer Res 55:2279-2283

106. Yang X, Ferguson AT, Nass SJ, Phillips DL, Butash KA, Wang SM, Herman JG, Davidson NE (2000) Transcriptional activation of estrogen receptor alpha in human breast cancer cells by histone deacetylase inhibition. Cancer Res 60:6890-6894

107. Yang X, Phillips DL, Ferguson AT, Nelson WG, Herman JG, Davidson NE (2001) Synergistic activation of functional estrogen receptor (ER)-alpha by DNA methyltransferase and histone deacetylase inhibition in human ER-alpha-negative breast cancer cells. Cancer Res 61:7025-7029

108. Fan J, Yin WJ, Lu JS, Wang L, Wu J, Wu FY, Di GH, Shen ZZ, Shao ZM (2008) ER alpha negative breast cancer cells restore response to endocrine therapy by combination treatment with both HDAC inhibitor and DNMT inhibitor. J Cancer Res Clin Oncol 134:883-890

109. Fortunati N, Bertino S, Costantino L, De Bortoli M, Compagnone A, Bandino A, Catalano MG, Boccuzzi G (2010) Valproic acid restores ER alpha and antiestrogen sensitivity to ER alpha-negative breast cancer cells. Mol Cell Endocrinol 314:17-22

110. Zhou Q, Shaw PG, Davidson NE (2008) Inhibition of histone deacetylase suppresses EGF signalling pathways by destabilizing EGFR mRNA in ER-negative human breast cancer cells. Breast Cancer Res Treat 117(2):443-451

111. Rayala SK, Molli PR, Kumar R (2006) Nuclear p21-activated kinase 1 in breast cancer packs off tamoxifen sensitivity. Cancer Res 66:5985-5988

112. Balasenthil S, Sahin AA, Barnes CJ, Wang RA, Pestell RG, Vadlamudi RK, Kumar R (2004) p21-activated kinase-1 signal- 
ling mediates cyclin D1 expression in mammary epithelial and cancer cells. J Biol Chem 279:1422-1428

113. Holm C, Rayala S, Jirstrom K, Stal O, Kumar R, Landberg G (2006) Association between Pak1 expression and subcellular localization and tamoxifen resistance in breast cancer patients. $\mathrm{J}$ Natl Cancer Inst 98:671-680
114. Munster PN, Lacevic M, Schmitt M, Bicaku E, Marchion D, Stephens A, Sullivan L, Minton S (2008) Phase II trial of vorinostat, a histone deacetylase inhibitor to restore the hormone sensitivity to the anti-estrogen tamoxifen in patients with advanced breast cancer having failed prior aromatase inhibitor therapy. J Clin Oncol 26:3501 